\title{
Synthesis, Characterization and Biological Activity of Novel Zirconium, Zinc and Cadmium Complexes Derived from Substituted Tetramethyl Guanidine
}

\author{
Hoda Pasdar ${ }^{1}$, Naser Foroughifar ${ }^{1}$, Bahare Hedayati Saghavaz ${ }^{1}$, Mehran Davallo ${ }^{1}$ \\ ${ }^{1}$ Department of Chemistry, Tehran North Branch, Islamic Azad University, Tehran, Iran \\ Correspondence: Hoda Pasdar, Department of Chemistry, Tehran North Branch, Islamic Azad University, Tehran, Iran. \\ E-mail: H_pasdar@iau-tnb.ac.ir
}

Received: May 23, 2017 Accepted: June 15, 2017 Online Published: June 20, 2017

doi:10.5539/ijc.v9n3p49 URL: https://doi.org/10.5539/ijc.v9n3p49

\begin{abstract}
A novel series of metal complexes of guanidine ligand derived from condensation of 1,1,3,3-tetramethylurea and 2-aminopyridine in present of $\mathrm{POCl}_{3}$ have been synthesized. The complexes are characterized using FTIR, UV-Vis and also molar conductance was measured. These spectroscopic studies confirmed that the ligand bonded to the metals through the nitrogen atoms. The suggested structures of the metal complexes are square planner. The ligand and its metal complexes were tested against Gram-negative bacteria; Escherichia coli, Serratia marcescens and Gram-positive bacteria; Bacillus sabtilis and Staphylococcus aureus by applying disc diffusion method. The most antibacterial activity of synthesized compounds belongs to $\mathrm{CdL}_{2}$ complex. The results of this study showed that the metal complexes have more antibacterial activity against species when compared to the parent ligand.
\end{abstract}

Keywords: Guanidine, $\mathrm{POCl}_{3}$, disc diffusion method, antibacterial activity

\section{Introduction}

Bacterial infections and bacteria drug resistance are very common all around the world. Also modern life and working conditions afford an encouraging environment for rapid evolution of microorganisms (Afradi et al., 2017). Therefore, in order to solve this important issue, it is necessary to improve effective antimicrobial agents to control the bacterial infection. As a result, antibacterial compounds that can efficiently inhibit the growth of microorganism with limited cytotoxicity have stimulated considerable attention in research fields (Behmaram et al., 2017). In recent years, the application of inorganic antibacterial agents has attracted much attention for the control of pathogenic microorganisms (Hedayati Saghavaz et al., 2017).

Guanidine, has already gained excessive attention since its discovery, due to their chemical and biological properties (Manetti et al., 2009). They also appear in a number of important antibiotic drugs including: Streptomycin, Trimethoprim, Chlorhexidine, Polyhexamethylene bi guanidine, Pyrrplidine bis-cyclic guanidine and others (Ghulam Murtaza, 2012). They can be used for urinary tract infection and disinfectant for swimming pools and wound care. In 2008 L.Qian et al. reported the synthesis of a novel guanidine polymer which has high antimicrobial activity against Escherichia coli and Staphylococcus aureus. In the present of $1 \mathrm{wt} \%$ of this compound in wood fibers, the growing inhabitation reached nearly 100\% (L. Qian et al., 2008).

In addition, transition metal complexes derived from guanidines have been found to exhibit some biological properties like antibacterial and antifungal activities (Cesme et al., 2015). The important pathogens such as Escherichia coli, Serratia marcescen, Bacillus sabtilis, and Staphylococcus aureus have wildly caused many diseases, so antibacterial activity of these complexes against four kinds of bacteria have been established. Present work describe the synthesis and antibacterial activity of metal complexes derived from 1,1,3,3-tetramethyl-2-(pyridin-2-yl)guanidine. The antibacterial activity of synthesized compounds compared to standard antibiotic drugs against gram-negative and gram-positive bacterial strains.

\section{Experimental}

\subsection{Material and Equipment}

All chemical and solvents purchased from Merck and Aldrich Company and used without further purification. $\mathrm{ZnI}_{2}$, $\mathrm{CdCl}_{2} \cdot 2 \mathrm{H}_{2} \mathrm{O}$ and $\mathrm{ZrO}\left(\mathrm{NO}_{3}\right)_{2} \cdot 9 \mathrm{H}_{2} \mathrm{O}$ were used as metal salts. The IR spectra were taken with a Shimidzo 300 
spectrometer using potassium bromide pellets. ${ }^{1} \mathrm{HNMR}$ (nuclear magnetic resonance) spectra of ligand were recorded on a Brucker AMX $250 \mathrm{MHz}$ spectrometer in $\mathrm{DMS}^{-} \mathrm{d}_{6}$ solvent using tetramethyl silan as an internal reference. Melting points of compounds were measured with an electrothermal melting point apparatus and were not corrected. The molar conductance of the complexes in DMSO $\left(1 \times 10^{-3} \mathrm{M}\right.$ solution) was performed at $25{ }^{\circ} \mathrm{C}$ using oakton ECTestr 11 dual-range, conductivity tester. The Mass spectra for metal complexes were run at $70 \mathrm{eV}$ at $230{ }^{\circ} \mathrm{C}$ with Agilent technologies. The progress of the reactions was monitored by thin-layer chromatography (TLC) on silica gel polygram precoated TLC sheets.

\subsection{Procedure for Synthesis of 1,1,3,3-Tetramethyl-2-(Pyridin-2-yl)Guanidine (L)}

The corresponding ligand (L) prepared according to the previously published procedure (Foroughifar et al., 1993). To a solution of 1,1,3,3 tetramethyl urea (1 m mol) in $10 \mathrm{ml}$ dry benzene was added drop-wise to a solution of $\mathrm{POCl}_{3}(4 \mathrm{~m}$ $\mathrm{mol})$ in $20 \mathrm{ml}$ dry benzene. The reaction mixture stirred for $12 \mathrm{~h}$ at ambient temperature, then the solution of 2-aminopyridin $(1 \mathrm{~m} \mathrm{~mol})$ in $50 \mathrm{ml}$ dry benzene added in several portions. The resulting mixture refluxed for $44 \mathrm{~h}$ at 75 ${ }^{\circ} \mathrm{C}$. The precipitate dissolved in water and $\mathrm{NaOH} 25 \%$ to bring the solution $\mathrm{pH}$ to about 14 , followed by extraction with benzene. The organic layer evaporated in vacuum.

pale brown. Yield :(0.167 g, 87\%); m.p. 120-122 ${ }^{\circ} \mathrm{C}$. Selected IR data $\left(\mathrm{KBr}, \mathrm{v}_{\max }\left[\mathrm{cm}^{-1}\right]: 3421,3170,2927,1632,1567\right.$, $1386 ;{ }^{1} \mathrm{H}-\mathrm{NMR}\left(250 \mathrm{MHz}, \mathrm{DMSO}-\mathrm{d}_{6}\right) \quad \delta: 8.11-8.09 \mathrm{ppm}(1 \mathrm{H}, \mathrm{t}, \mathrm{Ar}-\mathrm{H}), 7.50-7.43 \mathrm{ppm}(2 \mathrm{H}, \mathrm{m}, \mathrm{Ar}-\mathrm{H}), 6.69-6.54 \mathrm{ppm}$ $(\mathrm{m}, 3 \mathrm{H}, \mathrm{Ar}-\mathrm{H}), 2.95-2.51 \mathrm{ppm}\left(\mathrm{m}, 18 \mathrm{H}, \mathrm{CH}_{3}\right)$, UV-Vis (DMSO): $\lambda_{\operatorname{Max}}=280,310 \mathrm{~nm}$.

\subsection{General Preparation of Metal Complexes}

The metal complexes were prepared by the addition of a hot methanol solution of the appropriate metal salt $(1 \mathrm{mmol})$ to the hot solution of the guanidine ligand $(2 \mathrm{mmol})$ in the same solvent $(25 \mathrm{~mL})$ under inert atmosphere of nitrogen. The resulting mixture was refluxed for 2-3 h. The solid product was filtered, washed with methanol and dried in vacuum desiccator.

\section{Bis(1,1,3,3-tetramethyl-2-(pyridin-2-yl)guanidine) zirconium $\left(\mathrm{ZrL}_{2}\right)$}

White solid; Yield: $(0.305 \mathrm{~g}, 70 \%)$; m.p. $>300^{\circ} \mathrm{C}$. Molar conductance in DMSO: 10 . Selected IR data $\left(\mathrm{KBr}, \mathrm{cm}^{-1}\right): 3430$, 2998, 2913, 1659, 1437, 703, 670. UV-vis (DMSO): $\lambda_{\mathrm{Max}}=240,300 \mathrm{~nm}$.

\section{Bis(1,1,3,3-tetramethyl-2-(pyridin-2-yl)guanidine)Zinc (ZnL $\left.{ }_{2}\right)$}

Pale yellow solid; Yield: $(0.267 \mathrm{~g}, 75 \%)$; m.p. $>300{ }^{\circ} \mathrm{C}$. Molar conductance in DMSO: 12 . Selected IR data $(\mathrm{KBr}, \mathrm{cm}-1)$ : 3437, 2996, 2913, 1660, 1437, 700, 669. UV-vis (DMSO): $\lambda_{\operatorname{Max}}=360,310,350 \mathrm{~nm}$.

\section{Bis(1,1,3,3-tetramethyl-2-(pyridin-2-yl)guanidine)cadmium ( $\left.C d L_{2}\right)$}

Creamy solid; Yield: $(0.343 \mathrm{~g}, 65 \%)$; m.p. $>300^{\circ} \mathrm{C}$. Molar conductance in DMSO: 8 . Selected IR data $\left(\mathrm{KBr}, \mathrm{cm}^{-1}\right): 3425$, 2999, 2915, 1657, 1437, 705, 609. UV-vis (DMSO): $\lambda_{\mathrm{Max}}=250-300 \mathrm{~nm}$.

\subsection{Antibacterial Screening}

Escherichia coli (ATCC: 25922), Serratia marcescens (ATCC: 13880) as gram negative bacteria as well as, Bacillus sabtilis (ATCC: 6633) and Staphylococcus aureus (ATCC: 6838) as gram positive bacteria were used for the test of antibacterial activity of synthesized compounds. All bacteria strains were maintained as stock strains in Microbank cryovials and kept at $-80^{\circ} \mathrm{C}$ until used. Microorganisms were cultured onto Muller Hinton Agar (MHA) plate and incubated for $18-24 \mathrm{~h}$ at $35{ }^{\circ} \mathrm{C}$. The density of bacteria cultures required for the test was adjusted to 0.5 McFarland. Disk diffusion method according to standard method was applied for the antibacterial activity (Shahi et al., 2015). Tetracycline, impeneme and cephradine were used as standards drugs for antibacterial measurements. The compounds $(0.02 \mathrm{~g})$ were dissolved in $1 \mathrm{~mL}$ DMSO. A bacterial culture (which has been adjusted to $0.5 \mathrm{McF}$ arland) was used to lawn Hinton agar plates using a sterile swab. The discs had been impregnated with synthesized compounds were placed on the Muller-Hinton agar surface. DMSO showed no activity against any bacterial strains. After incubation for 18-24 h at $35^{\circ} \mathrm{C}$, the diameter of each zone of inhabitation was measured $(\mathrm{mm})$. The results are presented in Figure 1.

\section{Results}

In this research work Zirconium(II), Zinc(II) and Cadmium(II) metal complexes of 1,1,3,3-tetramethyl-2-(pyridin-2-yl) guanidine have been prepared to explore their antibacterial properties. The complexes were prepared by adding methanol solution of metal salts to methanol solution of guanidine ligand in stoichiometric ratio 1:2. Table 1 shows the physical properties of ligand and its metal complexes. The molar conductivity of complexes was also calculated.The molar conductance values of all the complexes were in the range 8-12 siemens, which indicate the complexes are non-electrolytes. The method for synthesis of ligand and its complexes and their proposed structures is illustrated in Scheme 1. 


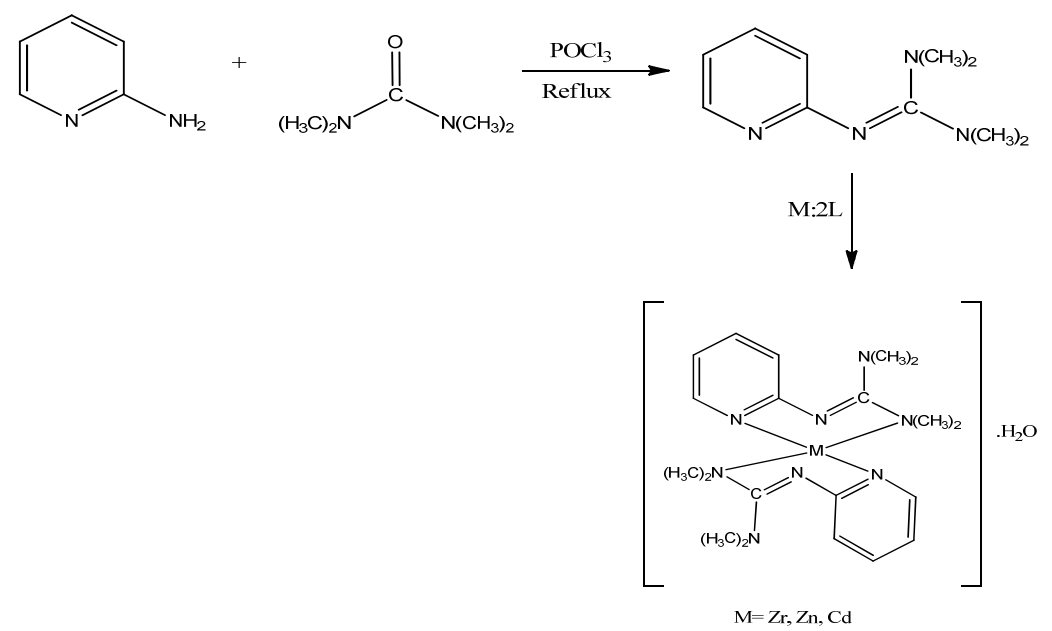

Scheme 1. Method for synthesis of guanidine ligand and its metal complexes

Table 1. Physical properties of ligand and its metal complexes

\begin{tabular}{cccccc}
\hline Compounds & Molecular formula & Color & Yield\% & $\begin{array}{c}\text { Molar } \\
\text { conductance }\end{array}$ & Melting point ${ }^{\circ} \mathrm{C}$ \\
\hline $\mathrm{L}$ & $\mathrm{C}_{10} \mathrm{H}_{16} \mathrm{~N}_{4}$ & Pale brown & 87 & - & $120-122$ \\
$\mathrm{ZrL}_{2}$ & $\mathrm{Zr} \mathrm{C}_{20} \mathrm{H}_{34} \mathrm{~N}_{4} \mathrm{O}$ & white & 70 & 10 & $>300$ \\
$\mathrm{ZnL}_{2}$ & $\mathrm{Zn} \mathrm{C}_{20} \mathrm{H}_{34} \mathrm{~N}_{4} \mathrm{O}$ & Pale yellow & 65 & 12 & $>300$ \\
$\mathrm{CdL}_{2}$ & $\mathrm{Cd} \mathrm{C}_{20} \mathrm{H}_{34} \mathrm{~N}_{4} \mathrm{O}$ & creamy & 75 & 8 & $>300$ \\
\hline
\end{tabular}

\subsection{Spectral Studies}

In the ${ }^{1} \mathrm{H}-\mathrm{NMR}$ spectrum of guanidine ligand, aromatic protons are appeared at 8.11-6.54 ppm as multiples and $\mathrm{CH}_{3}$ aliphatic protons are observed as multiples in $2.95-2.51 \mathrm{ppm}$.

In the FTIR spectrum of parent ligand, C-H (aromatic) and C-H (aliphatic) bands are observed in 3100 and $2927 \mathrm{~cm}^{-1}$ respectively. The $\mathrm{C}=\mathrm{N}$ frequency appear in $1632 \mathrm{~cm}^{-1}$ which confirm the formation of guanidine ligand. The FTIR spectra of ligand and its metal complexes were compared to characterize the metal complexes. In all the complexes $\mathrm{C}-\mathrm{H}$ (aromatic) and $\mathrm{C}-\mathrm{H}$ (aliphatic) bands are shifted to lower wavenumbers. The $\mathrm{C}=\mathrm{N}$ peaks in complexes appear in the range $1657-1660 \mathrm{~cm}^{-1}$. In the FTIR spectrum of parent ligand, the $\mathrm{C}-\mathrm{N}$ groups are observed in the range $1386-1220 \mathrm{~cm}^{-1}$ and these peaks shifted to the lower wavenumbers in all the metal complexes, which confirm the ligand is bonded to the metal ions through the nitrogen atoms. Also the $\mathrm{Zr}-\mathrm{N}, \mathrm{Zn}-\mathrm{N}$ and $\mathrm{Cd}-\mathrm{N}$ frequencies appear in 670,669 and $669 \mathrm{~cm}^{-1}$ respectively. The appearance of broad peaks in the range $34372-3430 \mathrm{~cm}^{-1}$ in all the complexes indicate the presence of $\mathrm{H}_{2} \mathrm{O}$ in the structure of all the compounds.

The electronic absorption spectra of the parent ligand and its metal complexes were recorded at ambient temperature using DMSO as the solvent. Electronic absorption of the free ligand shows bands at 280 and $310 \mathrm{~nm}$ which is assigned to $\pi \rightarrow \pi *$ and $n \rightarrow \pi *$ transitions, respectively. In the electronic spectra of all the metal complexes slight shifts are observed in these transition to the lower wavelength compared to the parent ligand. The Cadmium ( II ) complex shows a broad band in the range $250-300 \mathrm{~nm}$, Zirconium (II) complex shows peaks in the range 240 and $300 \mathrm{~nm}$ and Zinc (II) complex shows absorptions in the regions of 260,310 and $350 \mathrm{~nm}$.

The mass spectra of the complexes are in good agreement with the proposed structures. The molecular ion peaks for the Cadmium(II), Zirconium(II) and Zinc(II) complexes observed at $\mathrm{m} / \mathrm{z}=514,499$ and 467 respectively, are equal to their molecular mass. The other peaks in the mass spectrum were attributed to the fragmentation of the complex obtained from the rupture of different bonds inside the molecule.

\subsection{Biological Screening}

The antibacterial activity of synthesized compounds were evaluated against two gram positive (Bacillus sabtilis, Staphylococcus aureus) and two gram negative (Escherichia coli, Serratia marcescens) bacterial strains using disc diffusion method. All the synthesized compounds dissolved in DMSO to evaluate their antibacterial activity. DMSO showed no antibacterial activity against the species. The susceptibility of ligand and its metal complexes compared to tetracycline, imipenem and cephradine as standard antibiotic drugs. The results are shown in Figure 1. The results indicate that the metal complexes have higher antibacterial activity when compared to the parent ligand. This phenomenon can be explained on the basis of chelation theory (Pasdar et al., 2017). As can be seen in Figure 1 the 
guanidine ligand has moderate antibacterial activity. The diameter inhabitation zones of ligand are in the range 10-12 $\mathrm{mm}$. Among the studied metal complexes the $\mathrm{CdL}_{2}$ has higher antibacterial activity. The metal complexes showed more effective activity on $S$. marcescens compared to other pathogens.

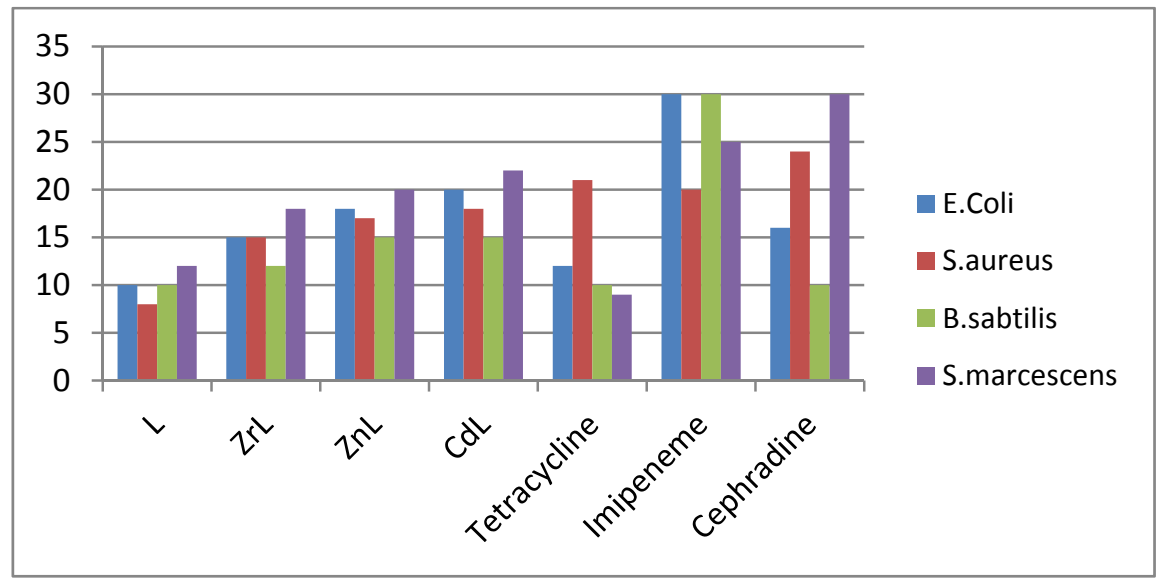

Figure 1. Graphical presentation of inhabitation zone diameter $(\mathrm{mm})$ of ligand and its metal complexes

\section{Conclusion}

In this paper, we report on the synthesis of Cadmium (II), Zirconium (II), and Zinc (II) complexes with 1,1,3,3-tetramethyl-2-(pyridin-2-yl) guanidine ligand. They were characterized by several spectroscopic methods. Square planner geometry was assigned for all the complexes. The antibacterial activities were screened for all the compounds by disc diffusion method. The Cadmium complex demonstrated higher antibacterial activity compared to other compounds.

\section{References}

Bahareh, B., Naser, F., Neda, F., \& Sara, H. (2017). Synthesis of some derivatives of 4-phenyl-1,3-dihydro-2H-imidazle-2-thion using ionic liquid as catalyst and evaluation of their antimivrobial activity. Inter. J. Chem., 9, 45-51. https://doi.org/10.5539/ijc.v9n2p45

Cesme, M., Golcu, A., \& Demirtas, I. (2015). New metal based drugs: Spectral, electrochemical, DNA-binding, surface morphology and anticancer activity properties. Spectrochim. Acta. A., 135, 887-993. https://doi.org/10.1016/j.saa.2014.06.144

Foroughifar, N., Leffek, K. T., \& Lee, Y. G. (1993). Synthesis and basicity of 2-N-quinolyl-and 2-N-isoquinolys-1,1,3,3-tetramethylguanidines, Can. J. Chem., 71, 164-169. https://doi.org/10.1139/v93-023

Ghulam, M., Muhammad, K. R., Amin, B., Masahiro, E., Muhammad, S., Marcel, G., ... Bushra, M. (2012). Eur. J. Med. Chem., 48, 26. https://doi.org/10.1016/j.ejmech.2011.11.029

Hedayati, B., Pasdar H., \& Foroughifar, H. N. (2016). Novel dinuclear metal complexes of guanidine -pyridine hybrid ligand: synthesis, structural characterization and biological activity. Biointerface Res. Appl. Chem., 6, 1842-1846.

Manetti, F., Castagnolo, D., Raffi, F., Zizzari, A. T., Rajamäki, S., Arezzo, S. D., ... Botta, M. (2009). Synthesis of new linear guanidines and macrocyclic amidinourea derivatives endowed with high antifungal activity against Candida spp. And Aspergillus spp, J. Med. Chem., 52, 73-76. https://doi.org/10.1021/jm900760k

Mojgan, A., Naser, F., Hoda, P., \& Hassan, M. (2016). Facile green one-pot synthesis of novel thiazolo[3,2-a] pyrimidine derivatives using Fe3O4@L-arginine and their biological investigation as potent antimicrobial agents. Appl. Organomet. Chem. https://doi.org/10.1002/aoc.3683

Pasdar, H., Foroughifar, N., \& Hedayati, B. (2017). synthesis, characterization and antibacterial activity of Co(II), Ni(II), $\mathrm{Mn}(\mathrm{II}), \mathrm{Cu}(\mathrm{II})$ and $\mathrm{Zn}(\mathrm{II})$ complexes with 2-amino, 7,7-dimethyl-5-oxo-4-chlorobenzen 5,6,7,8-tetrahydro-4H-chromone3-carbonitrile. Biotechnology and Biopharma, 1, 63-70.

Qian, L., Guan, Y., He, B., \& Xiao, H. (2008). Polymer, 49, 2471. https://doi.org/10.1016/j.polymer.2008.03.042

Shahi, M., Foroughifar, N., \& Mobinkhaledi, A. (2015) Synthesis and antimicrobial of some tetrahydro quinolone and pyrano[2,3-d] pyrimidine derivatives. Iran J. Pharm. Res., 14, 757-763.

\section{Copyrights}

Copyright for this article is retained by the author(s), with first publication rights granted to the journal.

This is an open-access article distributed under the terms and conditions of the Creative Commons Attribution license (http://creativecommons.org/licenses/by/4.0/). 